\title{
Cash Compensation, Corporate Governance, Ownership, and Dividend Policy on Banking Performance
}

\author{
Tafdil Husni*, Rida Rahim, Riyadi Aprayuda \\ Department of Management, Faculty of Economics \\ Andalas University \\ Padang, West Sumatra-Indonesia \\ *tafdilhusni@eb.unand.ac.id, ridarahim@eb.unand.ac.id, riyadiaprayuda@gmail.com
}

\begin{abstract}
This study analyzes the behavior of cash compensation, corporate governance, dividend policy and the performance of the Banking Industry in Indonesia. This study uses 33 go-public banks that are listed on the Indonesia Stock Exchange with 165 observations in 2014-2018. The analytical method uses Panel data regression with the Random Effect Model (REM). The results of the regression data obtained by the executive compensation had a significant positive effect on company performance, the proportion of compensation received by executives tended to have a direct impact on firm value. The results also showed that dividend policy had a significant positive effect on firm value, the greater the number of dividends distributed gave a positive signal to the market.
\end{abstract}

Keywords: corporate governance, dividends, the performance of the Banking Industry

\section{INTRODUCTION}

Banking performance is a major problem for policy makers and decision-makers mainly because it is the foundation for the stability and smooth functioning of the financial and banking system [1]. Bank's core competencies are not only inherent in the exchange of funds but also in their ability to manage credit risk. Interest income, which is considered as the main source of banking income, is generated to compensate for the operating costs of lending [2]. Poor bank performance is directly related to a weak economic-financial system. Bank performance is influenced by their operating models, governance, policies and ownership structure [3,4]. In Indonesia, credit risk, weak demand, and margin requirements are still the biggest risk challenges that must be faced in banking performance such as Wake [5] in a survey of banking directors shown in Figure 1.

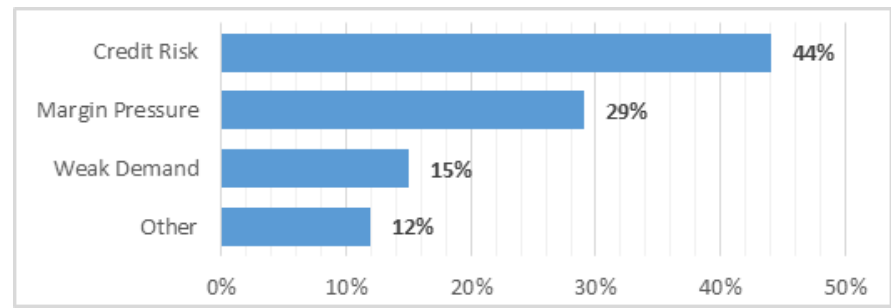

Fig. 1. Indonesia banking risk challenges (price waterhouse coopers Indonesia 2018).
To maintain financial stability requires the establishment of effective control mechanisms at banks, namely banking governance is one mechanism that maintains banking performance and is responsible for the difficulties facing the global economy [6]. Several studies, such as Shleifer and Vishny [7]; Baker and Gompers [8], found that governance mechanisms are expensive to implement. Jensen and Meckling [9] states that monitoring can reduce agency problems when insider ownership is low. Companies adopt governance mechanisms to align the interests of directors with shareholders [7]. The Basel Committee on Banking Supervision 2006 increases the need for banks to strengthen their governance practices.

Problems that arise in agency relationships are due to human nature (self-interest, bounded rationality, risk aversion) so that the agency theory is the organizational pressure (conflicting goals between members) and information (as a commodity that can be purchased) [10]. Efforts to minimize or control conflicts between agents and principals one of which is the structure of compensation and ownership of shares 41 , and consider CEO incentives or equity-based payments (stock options), salaries, bonuses and benefits as compensation that can improve performance [11], and can effectively minimize conflicts of interest [12]. Providing high compensation to executives / CEOs in the banking sector is expected to create productivity, profit, growth and minimize risk and improve banking performance. Principals can limit the divergence of their interests by providing an appropriate level of incentive to the agent and are willing to pay a monitoring fee to prevent the hazard from the agent. With the right compensation system for executives, it is expected that executives will not try to maximize their personal profits and remain focused on the company's main objectives. In fact the current conditions of high executive compensation can encourage executives to take too much risk (risk taking) that could endanger the stability of their company. The causes of the 2007-2008 global financial crisis, including high compensation. This shows that there is a moral hazard problem in executive / CEO behavior, which is a conflict of interest between owners and agents.

Seen from the perspective of banking performance and risk, banking directors in Indonesia are classified as risk-converters 
because they are very careful in providing credit and face the company's operational risk [13]. Because compensation payments based on cash incentives are considered less risky because they refer to performance results and are not based on market values such as equity compensation. According to the agency theory, the manager is an agent in the company and the shareholders are the owners of the company, each individual is only motivated by their respective interests for which executive compensation is present. Some arguments state that executive compensation must be linked to company performance. Conversely, some say executive rewards will benefit the company long-term but will not be seen in current performance [14].

Research Caprio et al. [15] proves compensation provides benefits for reducing bank risk, proxied by NPL (nonperforming loans), LDR (loan to deposit ratio), and OR (operational risk) which means giving compensation in cash in the form of salary, bonuses, and benefits are the implications of the results of the performance of the board of directors so as to reduce risk with NPL and OR proxies and overcome the problems of moral hazard (agency) in the banking industry. Supported by Athar et al. [16] revealed that there is a significant and positive correlation between company performance and CEO cash compensation (basic salary, bonuses, benefits and special allowances) in the Pakistani banking industry is highly dependent on the total assets of companies that have significant and positive impact. Rajgopal, and Shevlin [17] who found a significant relationship between compensation in the form of stock options on performance, in line with research by Coles et al. [18] found there is an effect of compensation structure on performance. Jensen and Murphy [19] states that there is a positive relationship between company performance and executive compensation. Attractive compensation will encourage executives to work to improve company performance and there is a positive relationship between salary payments and company performance [20-22]. In contrast, the results of the research by McKnight and Tomkins [23]; Veliyath [24] found compensation payments had no effect on performance. Supported by Firth [25], research there is no relationship between compensation payments and company performance. Balachandran et al. [13] found evidence that there was no relationship between CEO cash compensation and performance among developing country companies.

Ownership is also seen as reducing agency problems between shareholders and managers resulting from the separation between ownership and control [26]. In the banking case, Ungureanu [27] states that concentrated managerial ownership increases bank control and monitoring of its activities through better information flow. Large shareholders are more effective in exercising their rights, so they have more control over management. The existence of Big Managerial Ownership is also associated with high bank performance. Morck et al. [28] show that Managerial Ownership by corporate block holders is positively related to firm value, and Claessens et al [29]; Cole, and Mehran [30] found that there is a strong positive relationship between managerial ownership and profitability. On the other hand contrary to the findings of Berger et al.[31] managerial ownership was found to have a negative impact on performance. Companies with high concentrated ownership are more vulnerable to financial difficulties and crises.

Thillainathan [32] attributed the high concentration of ownership structure of Malaysian banks as one of the main factors that caused banks to suffer severe financial difficulties in 1998. With the presence of large shareholders with high authority to make decisions and control management creates long-term moral hazard behavior affect bank performance. This is because large shareholders tend to behave independently by making decisions that will maximize their profits even though these decisions can increase bank risk and endanger the longterm performance of the bank and the viability of the bank. Different types of shareholders always have priorities (insiders and outsiders ownership, different preferences and goals. Ongore [33]; Porta et al. [34] find that the type of ownership structure determines company performance. The difference in ownership structure has two consequences. It is clear that, controlling shareholders have the incentive and power to discipline management and, controlling shareholders can create conditions for new problems when their interests are not aligned with the interests of minority shareholders [28].

Other factors that affect banking performance and risk are dividend payments [35]. Companies consider dividend decisions to be quite important because they determine what funds flow to investors and what funds are kept by companies for investment. Dividend policies can also provide information to stakeholders about company performance and signal future company performance [36-40]. But recently, the results have been mixed that dividend changes do not predict future earnings growth in companies [41,42]. On the other hand, large amounts of dividends can cause defaults, and therefore must be avoided by banks paying large amounts of dividends to shareholders during a crisis [43], on the other hand, banks are encouraged to increase bankruptcy risk. This type of moral hazard behavior can be caused by regulations that isolate bank owners from bankruptcy risk (implied bailout guarantees).

This study aims to broaden the gap filled with previous research, and by looking at the effects of governance, cash compensation, ownership, on company performance. Specifically, this study highlights the relationship between company performance and compensation for directors, dividends, managerial ownership, ownership institutions, independent boards, annual meeting frequency size. The next section is presented to review the relevant literature and explain our hypothesis. Acharya et al. [43] presented to illustrate the data and methodology. Finally, Adesina [44] discusses the research findings and Agbatogun, and Adewumi [38] presents conclusions and implications.

\section{RELATED LITERATURE AND HYPOTHESIS DEVELOPMENT}

An agency relationship is a contract between one person or more (principal) and another person (agent) were the principal delegates the decision-making authority of the agent to do some work on their behalf [25]. Principals have limitations in managing the company so they hand over management responsibilities to the agent. The management which is obliged to manage the company is expected to be able to increase the 
principal's welfare through increasing the company's value. If that can be realized, they will get rewards in the form of bonuses and other compensation.

The separation of ownership and control of the company between the owner (principal) and management (agent) tends to cause agency conflict. This arises because agents do not always act in the interests of the principal alone. Agents have the authority to manage the company so that they do not rule out the possibility that they determine policies that also maximize their well-being. Eisenhardt [10] explains that there are three assumptions about human nature, namely: Humans tend to be more selfish (self-interest), Humans have limited information, cognitive abilities, and time in decision making (bounded rationality), and humans tend to avoid risk (riskaverse). Based on these assumptions, principals and agents as humans will naturally act opportunistically in their interests.

Company value is the investor's perception of the company, which is often associated with stock prices. The value of a company formed through stock market indicators is greatly influenced by investment opportunities. Investment expenditure gives a positive signal to managers about the company's growth in the future, thus increasing stock prices as an indicator of company value. High stock prices make the value of the company also high [45]. In this study, the authors chose Tobin's Q because this indicator is accurate to measure the performance of companies affected by executive compensation. Also, the measurement of company performance using Tobin's Q not only provides an overview of the fundamental aspects but the extent of assessing the company from various aspects seen by outsiders including investors. Tobin's Q represents several important variables in measuring performance, including the company's listed assets, adequate market trends, and intangible asset variables.

Providing compensation is also one of how the company owner deals with agency conflicts that often occur within the company due to information asymmetry. Jensen and Murphy [19] states that the provision of compensation packages can be used to overcome the problem of moral hazard management. The higher compensation will be given, the company hopes to minimize risk and management performance will increase.

Research on executive compensation for performance has been carried out by previous researchers found a significant relationship between cash compensation and performance [1722]. The first hypothesis propose is:

- H1: Compensation has a positive effect on banking performance

Firth et al. [25] explain that ownership structure shows the large percentage of share ownership by insider (management) and outsider (investors who do not have a direct role in company management. In addition, ownership structure can act as a form of commitment to delegate control to a certain degree at management [46]. Shareholders with large share ownership have voting rights that can control management, whereas if shareholders own only a small portion of the company's shares, it will be difficult for them to control managerial activities, Caprio et al. [15] classify ownership in the bank becomes two, namely if the shareholder has control rights and cash flow rights directly and indirectly of $10 \%$ or more then it is called a large shareholder and vice versa, if the shareholder has control rights and cash flow rights of less than $10 \%$, then the bank classified as widely he ld. The results showed that ownership in an institution also influences the activities in it. The series of activities ultimately has implications for the performance process and decision-making behavior. This also happens in the banking industry, the identity of ownership in the bank will also determine the risk taking and banking performance $[47,48]$.

Research on ownership of banking performance has been carried out by previous researchers such as Claessens et al. [29]; Cole and Mehran [30] found that there is a strong positive relationship between managerial ownership and company performance. Mangel and Singh [49] also state that a good level of supervision of management within a company is positively related to the high percentage of institutional ownership. Thus the proportion of institutional ownership acts as a deterrent to waste by management. Ongore [33] and Porta et al. [34] find that the type of ownership structure determines performance. The second and third hypothesis propose is:

- H2: Managerial ownership has a positive effect on banking performance

- H3: Institutional ownership has a negative effect on banking performance

Dividend is the distribution of cash or other assets to shareholders proportionally (based on the number of shares owned) [11]. Dividend policy is a decision to determine how much of the company's profits will be distributed to shareholders and will be retained in the form of retained earnings to finance investment in the future Dividend policy can be used as a means to overcome agency problems between corporate management and shareholders According to this assumption, if profits are not distributed to shareholders, there is a concern that earnings will be used for personal benefit management or for the procurement of unprofitable projects that tend to spend company money. Therefore, shareholders will prefer dividends rather than retained earnings [50].

According to Acharya et al. [51], the best solution for banks that carry out high risk-taking is to hold back their cash flow for the sake of bank capital adequacy because the bank has a high potential for default. However, Acharya et al. [46] found the fact that banks actually use their cash flow to pay dividends. This happens because the dividend policy is regulated to maximize shareholder value. Onali [52] also states that in non-financial companies, high risk-taking results in low dividend distribution (negatively related), but in the banking industry (public guarantee) there is a possibility that the two will be positively related.

Research on dividend policy on company performance has been done by previous researchers found that dividend policy can also provide information to stakeholders about company performance and signal future company performance [3640,44]. The fourth hypothesis propose is:

- H4: Bank dividends have a positive effect on bank performance 
TABLE I. DESCRIPTIVE STATISTICS there are rules regarding meetings / meetings that must be conducted by the board of commissioners and directors. According to the regulation, the board of commissioners is required to hold regular meetings at least four times a year and directors are required to meet once a month. For this reason, the number of meetings of the board of commissioners and directors is used for one year or annual meeting frequency. Several components in board characteristics, namely board size, board meeting, independent board, busyness board, and duality board, produce that board meeting has a positive impact on company performance [54]. The fifth hypothesis propose is:

- H5: Annual meeting frequency has a positive effect on banking performance

\section{METHODS}

The unit of analysis of this research is the bank. Population is a public company whose shares are listed on the IDX. The research period is 5 years (2014-2018), involving banks with 165 observations. Specifically, the financial sector in Indonesia has determined the grouping of various core capital sizes of banks that have been set by the regulator, but we do not follow the grouping of banks here only focus on the mechanism of cash compensation, ownership, dividends, independent boards, annual meeting frequency and company size. The type of data used in this study is secondary data, namely the company's annual report on the Indonesia Stock Exchange

Analysis of PLS model selection is done by a fixed-effect model (FEM) and then between FEM and REM models can be seen in the results of the Chow and Hausman test. The Chow test results show that Prob $=0.0000$ for cross section F, which is less than 0.05 , so $\mathrm{H} 0$ is rejected. Therefore, it can be concluded that with a $95 \%$ confidence level, the panel model is better than the general effect model. Then the Hausman test was carried out, yielding a Prob $=0.0306$ for a random cross section, which was smaller than 0.05 . The decision is to accept $\mathrm{H} 0$ so that it can be concluded that with a $95 \%$ confidence level, the effect model is still better than the random model.

Tobin'Qit $=\alpha$ oi $+\beta 1$ CompBODit $+\beta 2$ Dev it + $\beta 3$ Owmanagit $+\beta 4$ Owninstit $+\beta 5$ IndpBit $+\beta 6$ AMFit $+\beta 7$ Sizeit + eit

\section{A. Data Analysis Method}

The data used in this research is secondary data. The acquisition method used for secondary data is the documentation method. Some data obtained from financial statements published in the company. The descriptive statistical analysis shown in Table I illustrates company-specific variables, namely Performance (Tobin'Q), EC (Compensation of directors), Dev (Dividend), MO (Managerial Ownership), IndpB (Independent Board of Ownership of Institutional) IO (Independent Board), AMT (Annual meeting frequency), SIZ (company size).

\begin{tabular}{|l|l|l|l|}
\hline \multicolumn{1}{|c|}{ Variable } & \multicolumn{1}{|c|}{ Mean } & \multicolumn{1}{c|}{ Maximum } & \multicolumn{1}{c|}{ Minimum } \\
\hline Tobin'Q & $\begin{array}{l}1.034246 \\
(0.251436)\end{array}$ & 1.669502 & 0.239458 \\
\hline Deviden & $\begin{array}{l}0.3750 \\
(0.0276)\end{array}$ & 1.0000 & 0.0000 \\
\hline LOG EC & $\begin{array}{l}10.39672 \\
(1.366123)\end{array}$ & 13.33848 & 7.886457 \\
\hline MO & $\begin{array}{l}0.01152 \\
(0.00245)\end{array}$ & 0.76543 & 0.0000 \\
\hline IO & $\begin{array}{l}0.033528 \\
(0.2283)\end{array}$ & 0.720688 & 0.0384 \\
\hline Ind Board & $\begin{array}{l}0.962422 \\
(0.348268)\end{array}$ & 1.609438 & 0.0000 \\
\hline LOG AMF & $\begin{array}{l}3.560071 \\
(0.614707)\end{array}$ & 5.455321 & 1.609438 \\
\hline LOG Size & $\begin{array}{l}15.3128 \\
(0.4770)\end{array}$ & 17,8545 & 11.2269 \\
\hline Observation & 165 & \multicolumn{2}{|l}{} \\
\hline
\end{tabular}

Table 1 represents the parameter coefficients of the descriptive statistic results, maximum, minimum, mean, median, and standard deviation

TABLE II. COLLINEARITY TEST

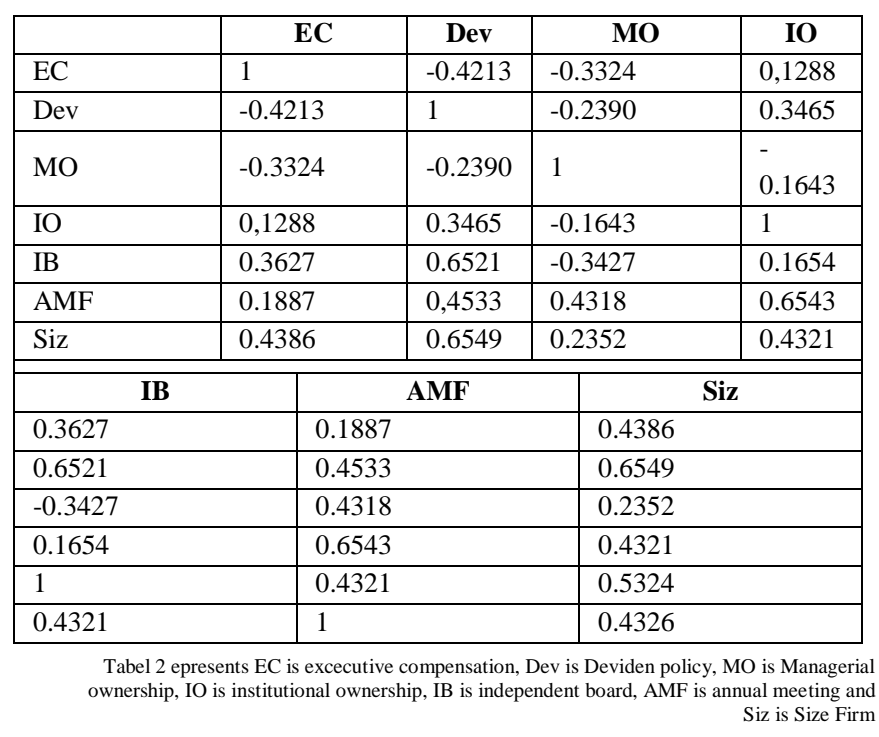

Table II explains the correlation matrix. From the correlation matrix, it is illustrated that EC (Board of Directors compensation), IO (Ownership of Institutional), IndpB (Independent Board), AMT (Annual meeting frequency), SIZ (company size) are positively correlated with Performance (Tobin'Q), this shows an indication every time there is an increase in these variables add to the company's performance besides Dev (Dividend), MO (Managerial Owners), negatively correlated with Performance (Tobin'Q). This shows the fact that every time there is an increase in these variables will reduce company performance. Table 2 also explains the results of the correlation test between the research variables, the correlation value between the independent variables shows that there are no symptoms of multicollinearity. This can be seen from the correlation between independent variables $<0.8$. 


\section{RESULTS AND DISCUSSION}

Table III presents the results of multiple linear regression tests of cash compensation, ownership, dividends, independent boards, annual meeting frequency and company-specific factors such as company size. Estimation results and statistical models show the significant impact of cash compensation on company performance.

TABLE III. REGRESSION RESULTS

\begin{tabular}{|l|l|}
\hline \multicolumn{1}{|c|}{ Variable } & \multicolumn{1}{|c|}{ Coefficient } \\
\hline C & $\begin{array}{l}-0.063143 \\
(0.0005)\end{array}$ \\
\hline EC & $\begin{array}{l}0.23208 \\
(0.0584) * * *\end{array}$ \\
\hline Dev & $\begin{array}{l}0.003982 \\
(0.05932)\end{array}$ \\
\hline MO & $\begin{array}{l}0.056781 \\
(0.12768)\end{array}$ \\
\hline IO & $\begin{array}{l}0.01638 \\
(0.14387)\end{array}$ \\
\hline IndpB & $\begin{array}{l}-0.008403 \\
(0.13436)\end{array}$ \\
\hline Siz & $\begin{array}{l}0.00745 \\
(0.03126) * *\end{array}$ \\
\hline R- squared & 0.184634 \\
\hline Adjusted R-squared & 0.145618 \\
\hline F-statistic & .481146 \\
\hline Prob(F-statistic) & 0.001045 \\
\hline
\end{tabular}

Cash compensation test results have a positive Cash compensation test results have a positive influence on company performance. These results indicate cash compensation given to bank executives will have an impact on company performance [18]. This happens because attractive compensation will encourage executives to work to improve company performance. This makes Hypothesis 1 accepted in line with several previous studies compensation provided will give an indication of improved performance [20-22]. The higher the cash compensation such as basic salary, bonuses, benefits, and special allowances are given to directors, the better the performance of directors and encourage company performance [13].

Meanwhile, Dividends have a significant positive effect on company performance. This result shows because the dividend policy decision is quite important because it determines what funds flow to investors and what funds are kept by companies for investment. This makes Hypothesis 4 accepted in line with some previous studies [35-37,39,40,44]. Dividend policy can also provide information to stakeholders about company performance and signal future company performance. The greater the amount of dividends distributed gives a positive signal to the market.

The role of managerial, institutional and independent board ownership does not affect because companies owned by the founding family or the board of directors and commissioners themselves lack incentives to manage income, because they do not have high pressure to meet or beat income expectations [55]. The results of this study produce that the two types of ownership structure and independent board do not influence performance, the results of this study are not in line with
Ongore [33], Porta et al. [34] found that the type of ownership structure determines company performance.

Similarly, ownership and independence of the frequency of meetings held also does not provide an increase in performance. It seems that in Indonesian banking, ownership identity in the bank does not determine risk-taking and banking performance and the performance is still influenced by other factors and the independent role of the board has not been able to show an increase in performance.

The results of testing the size control variable on the performance show the effect. This indicates that the size differences in banks show different performance, the bigger the size, the better the bank's performance and vice versa.

\section{CONCLUSIONS AND IMPLICATIONS}

Based on the results of the study, it can be concluded that compensation increases the value of the company. This means that the provision of cash compensation in the form of salary, bonuses, and incentives is considered as an implication given from executive performance. The results of this study indicate that the variable executive compensation, dividend, and size are variables that have a significant positive effect on Tobin's Q. cash in the form of salaries, bonuses, and incentives is considered as the implications given from executive performance so as to improve company performance, with the motive behavior of bank executives who expect or obtain higher compensation and continue to want to increase the value of the company. Dividend policy can also provide information to stakeholders about the company's performance as well as signal the company's performance in the future. The greater the amount of dividends distributed gives a positive signal to the market.

These findings are consistent and provide evidence to support agency theory, namely that the provision of compensation is also an effective way for company owners to deal with agency conflicts that often occur within the company caused by information asymmetry, the higher the compensation that will be given, the company hopes can minimize risk and improve management performance. This research indicates that compensation in Indonesian banking companies is still the thing that drives performance, interesting compensation will encourage Indonesian banking executives to try to improve company performance so as to increase company value. Giving sufficient compensation and dividends can be used as a strategy to improve the performance of directors in managing the company.

Research suggestions in the future researchers can extend the observation period so that the research outcome variables are more accurate, specific on the separation of conventional and Islamic banks which are not considered in this study and look at instruments for improving performance in Islamic banks or comparing them to Indonesian banks as a country with Muslims most, it is also hoped that further research will separate compensation between directors, commissioners and management and can sort compensation in depth. 


\section{REFERENCES}

[1] F.A.M. Shawtari, "Ownership type, bank models, and bank performance: the case of the Yemeni banking sector," International Journal of Productivity and Performance Management, vol. 67, no. 8, pp. 1271-1289, 2018.

[2] R. DeYoung and T. Rice, "Noninterest income and financial performance at US commercial banks," Financial Review, vol. 39, no. 1, pp. 101-127, 2004.

[3] T. Beck, A. Demirgüç-Kunt, and O. Merrouche, "Islamic vs conventional banking: business model, efficiency and stability," Journal of Banking and Finance, vol. 37, no. 2, pp. 433-447, 2013.

[4] A. Dietrich and G. Wanzenried, "Determinants of bank profitability before and during the crisis: evidence from Switzerland," Journal OfInternational Financial Markets, Institutions and Money, vol. 21, no. 3, pp. 307-327, 2011.

[5] D. Wake and L. Suhenda, 2018 Indonesia Banking Survey Technology shift in Indonesia is underway, 2018. Retrieved from https://www.pwc.com/id/en/publications/assets/financialservices/2018indonesia-banking-survey.pdf

[6] M.A. Ayadi, N. Ayadi, and S. Trabelsi, "Corporate governance, European bank performance and the financial crisis," Managerial Auditing Journal, vol. 34, no. 3, pp. 338-371, 2019.

[7] A. Shleifer and R. Vishny, "A Survey of Corporate Governance," The Journal of Finance, vol. 2, no. 1, pp. 737-783, 1997.

[8] M. Baker and P. Gompers, "The determinants of board structure at the initial public offering," Journal OfLaw and Economics, vol. 46, no. 2, pp. 569-598, 2003.

[9] M.C. Jensen and W.H. Meckling, "Theory of the firm: Managerial behavior, agency costs and ownership structure," Journal of Financial Economics, vol. 3, no. 3, pp. 305-360, 1976.

[10] K.M. Eisenhardt, "Agency theory; an assessment and review," Academy of Management Review, vol. 14, no. 1, pp. 57-74, 1989.

[11] D.E. Kieso, J.J. Weygandt, and T.D. Warfield, Intermediate Accounting, 14th ed., United State of America: Jhon Wiley \& Sons Inc., 2011.

[12] D. Yermarck, "Do corporate award CEO stock options effectively?" Journal of Financial Economics, vol. 39, pp. 237-269, 1995.

[13] S. Balachandran, B. Kogut, and H. Harnal, The Probability of Default, Excessive Risk, and Executive Compensation: A Study of Financial Services Firms from 1995 to 2008, Berlin: WZB, 2010.

[14] N. Balafas, and C. Florackis, "CEO compensation and future shareholder returns: Eviden from the London Stock Exchange,” Journal of Empirical Finance, 2013.

[15] G. Caprio, L. Laeven, and R. Levine, "Governance and bank valuation," Journal of Financial Intermediation, vol. 16, no. 1, pp. 584-617, 2007.

[16] I. Athar, M.I. Khan, and S. Ali, "CEO Compensation and Bank Performance CEO Compensation and Bank Performance," MPRA Paper, 2012.

[17] S. Rajgopal and T. Shevlin, "Empirical evidence on the relation between stock option compensation and risk taking," Journal of Accounting and Economics, vol. 33, no. 1, pp. 145-171, 2002.

[18] J.L.Coles, N.D. Daniel, and L. Naveen, "Managerial Incentives and Risk-Taking," Journal of Financial Economics, vol. 79, no. 1, pp. 431468, 2006.

[19] M. Jensen and K. Murphy, "Performance Pay and Top Management Incentives," Journal of Political Economy, vol. 98, no. 1, pp. 225-264, 1990.

[20] M. Conyon, P. Gregg, and S. Machin, "Taking Care of Business: Executive Compensation in the United Kingdom," The Economic Journal, vol. 105, no. 1, pp. 704-714, 1997.

[21] H. Ingham and S. Thompson, "Mutuality, Performance and Executive Compensation," Oxford Bulletin of Economics and Statistics, vol. 57, no. 3, pp. 295-308, 1995.

[22] P.J. McKnight, "An Explanation of Top Executive Pay: A UK Study," International Journal of Employment Relations, vol. 34, no. 4, pp. 557$566,1996$.
[23] P.P. McKnight and C. Tomkins, "Top Executive Pay in the United Kingdom: A Corporate Governance Dilemma," International Journal of the Economics of Business, vol. 6, no. 2, pp. 223-243, 1999.

[24] R. Veliyath, "Top Management Compensation and Shareholder Returns: Unravelling Different Models of the Relationship," Journal of Management Studies, vol. 36, no. 1, pp. 123-143, 2002.

[25] M. Firth, J.C. Lohne, R. Ropstad, and J. Sjo, "The Remuneration of CEOs and Corporate Financial Performance in Norway," Managerial and Decision Economics, vol. 17, no. 1, pp. 291-301, 1996.

[26] A.N.A.A. Rahman and B.A.F.M. Reja, "Ownership Structure and Bank Performance," Journal of Economics, Business and Managemen, vol. 3, no. 5, pp. 483-488, 2015.

[27] M.S. Ungureanu, "Banks: regulation and corporate governance framework," Journal of Ownership and Control, vol. 5, no. 2, pp. 1-19, 2008.

[28] R. Morck, M. Nakamura, and A. Shivdasani. "Bank, ownership structure and firm value in Japan," Journal of Business, vol. 73, no. 1, pp. 539567, 2000.

[29] S.Claessens, S. Djankov, and L. Lang, "The separation of ownership and control in East Asian corporations," Journal of Financial Economics, vol. 58, no. 1, pp. 81-112, 2000.

[30] R.A. Cole and H. Mehran, "The Effect of changes in ownership structure on performance: Evidence from the trift industry," Journal of Financial Economics, vol. 50, no. 1, pp. 291-317, 1998.

[31] A. Berger, G. Clarke, R. Cull, L. Klapper, and G. Udell. "Corporate governance and bank performance: A joint analysis of the static, selection and dynamic effects of domestic, foreign and state ownership," Journal of Banking and Finance, vol. 29, no. 1, pp. 2179-2221, 2005.

[32] R. Thillainathan, Corporate governance and restructuring in Malaysia, a review of markets, mechanisms, agents and the legal infrastructure. Number of Asian Countries, 1999.

[33] V.O. Ongore, "The relationship between ownership structure and firm performance: An empirical analysis of listed companies in Kenya," African Journal of Business Management, vol. 5, no. 6, pp. 2120-2128, 2011.

[34] R.L. Porta, F. Silanes, and A. Shleifer, "Government ownership of banks," The Journal of Finance, vol. 57, no. 1, pp. 265-301, 2002.

[35] Ross, Westerfield, and Jaffe, Corporate Finance, 6th Ed., New York: Mc. Graw-Hill, 2002.

[36] A.B. Abdella and V. Manual, "A Study on thDeterminants of Dividend Policies of Commercial Bankin Saudi Arabia," Imperial Journal of Interdisciplinary Research, vol. 2, no. 1, pp. 12-24, 2016

[37] Abiola, "Measuring and Analyzing the Effects Of Dividend Policy In Banking Profits And Growth," Journal of Policy and Development Studies, vol. 9, no. 1, 2014.

[38] T. Agbatogun and A. Adewumi "The Nexus of Dividend Payout and Profitability Performance of Insurance firms in Nigeria," SSRN Electronic Journal, 2017.

[39] A. Ajanthan, "A Nexus Between Liquidity \& Profitability: A Study Of Trading Companies In Sri Lanka," European Journal of Business and Management, vol. 5, no. 7, pp. 221-237, 2013.

[40] S. Karpavičius, "Dividends: Relevance, Rigidity, and Signaling Abstract," Journal of Corporate Finance, vol. 25, no. 1, pp289-312, 2014.

[41] D. Datta, S.K. Ganguli, and M. Chaturvedi, "Announcement Effect of Dividend in Presence of Dividend Tax: Possible Agency Problem and Macro Level Inefficiency?" South Asian Journal of Macroeconomics and Public Finance, vol. 3, no. 2, pp. 195-220. 2014.

[42] T. David and E. Ginglinger, "When cutting dividends is not bad news : The case of optional stock dividends," Journal of Corporate Finance, vol. 40, no. 1, pp. 174-191, 2016.

[43] V. Acharya, T. Philippon, M. Richardson, and N. Roubini, "Prologue : A Bird' s Eye View The Financial Crisis of 2007-2009: Causes and Remedies," Financial Markets Institutions \& Instruments, vol. 18, no. 2, pp. 89-137, 2009.

[44] K. Adesina, U. Uwuigbe, O.R. Uwuigbe, and S. Oriabe, "Dividend Policy and Share Price Valuation in Nigerian Banks," Macroeconomics And Monetary Economics, vol. 1, no. 36, pp. 1-12, 2017. 
[45] Brealey, Fundamentals Of Corporate Finance, 10th ed., New York: McGraw-Hill, 2007.

[46] V. Acharya, L.P. Litov, and S.M. Sepe, "Seeking Alpha, Taking Risk: Evidencefrom Non-executive Pay in U.S. Bank Holding Companies," Working papers, 2014.

[47] P. Nguyen, "Corporate Governance and Risk-Taking: Evidence from Japanese Firms," P. Pacific-Basin Journal, vol. 19, no. 1, pp. 278-297, 2011.

[48] N. Boubakri, J.C. Cosset, and W. Saffar, "The Role of State and Foreign Owners in Corporate Risk-Taking: Evidence from Privatization," Journal of Financial Economics, vol. 8, no. 1, pp. 641-658, 2013.

[49] R. Mangel, and H. Singh, "Ownership Structure, Board Relationships and CEO Compensation in Large US Corporations," Accounting and Business Research, vol. 23, no. 91, pp. 339-350, 1993.
[50] T.A. Gumanti, Kebijakan Dividen Teori, Empiris, dan Implikasi, Jakarta: UPP STIM YKPN, 2013.

[51] V.V. Acharya, M. Pagano, P.F. Volpin, "Seeking Alpha: Excess Risktaking andCompetition for Managerial Talent," European Corporate Governance Institute ECGI - Finance Working Paper No. 398/2014, 2014.

[52] E. Onali, "Moral Hazard, Dividends, and Risk in Banks," Journal of Business Finance and Accounting, vol. 41, pp. 128-155, 2014.

[53] Financial Services Authority Regulation No. 33 / POJK.04 / 2014

[54] Q. Liang, P. Xu, and P. Jiraporn, "Board characteristics and Chinese bank performance," Journal of Banking and Finance, 2013.

[55] P. Jiraporn and P.J. Dadalt, "Does founding family control affect earnings management?" Applied Economics Letters, vol. 16,no. 1, pp. 113-119, 2009 